\title{
Knowledge, Attitudes and Practices (Kap) of Ebola Virus Disease: Enugu State Metropolis Survey in Nigeria
}

\author{
Article by Mgbe Chinenye Glory \\ Ph.D, Texila American University, Nigeria \\ Email: sischinny@yahoo.co.uk
}

\begin{abstract}
Background: The Ebola Virus Disease (EVD) outbreak was declared in Nigeria by the Federal Ministry of Health on 24th July 2014 following the arrival of a male passenger from Liberia. Aim: The study set to assess the knowledge, attitude and practices of Ebola Virus Disease among residents in Enugu, Eastern Nigeria. Primary care providers. Materials and Methods: A total 394 participants were recruited for this descriptive cross sectional study. Data was collected using structured interviewer administered questionnaire focusing on demographic characteristics, knowledge of Ebola virus disease, and infection control practices. Data analysis was carried out using SPSS version 15. Results: The results were expressed in percentages. It showed relatively low awareness (31 .0\% )about EVD with the female gender predominating. The most significant source being from the television media. Conclusion: The most important tool to fight EVD is correct adequate information through various media as prevention through improved personal hygiene is key.
\end{abstract}

Keywords: Attitude, Practice, Knowledge, Ebola Virus Disease, Community.

\section{Introduction}

The Ebola Virus Disease (EVD)outbreak was declared in Nigeria by the Federal Ministry of Health on 24th July 2014 following the arrival of a male passenger from Liberia whose condition degenerated inflight and necessitated evacuation to a hospital on his arrival in Lagos. The Laboratory tests conducted, confirmed that the traveler from Liberia had EVD.

Federal Ministry of Health reported a total of 19 cases confirmed Ebola in Nigeria including the imported case from Liberia on 23rd September, 2014. Of the 19 cases reported, 15 cases were from Lagos while 4 cases were from Rivers State. Ever since the first case was reported, there have been a total number of 891 contacts. 365 cases in Lagos and 526 cases in Rivers. A total number of 847 contacts underwent surveillance and completed the 21 days monitoring and were discharged, of which 349 were from Lagos and 498 Rivers.

Since the beginning of the epidemic, there have been seven deaths (five in Lagos and two in Rivers), 11 survivors that have been discharged in Lagos and one in Rivers with no confirmed case currently in isolation (CDC, 2014). As of 24th September 2014, there have been no more confirmed cases in Nigeria (WHO, 2014).

In Enugu state, 21 Ebola suspects underwent surveillance as a result of their involvement with the nurse who disobeyed medical instructions and left to Enugu and all the people who she had contact with, including her husband, were quarantine. The medical team was able to trace all those who made contact with her but there was no case of confirmed death.

The Ebola outbreak in West Africa is the world's deadliest to date. On 8th August, 2014, World Health Organization (WHO, 2014) declared an international health emergency in Africa as over 3,850 peoples have died of the virus in Guinea, Liberia, Sierra Leone and Nigeria. It has spread between countries starting in Guinea and then spreading across land borders to Sierra Leone and Liberia, moved by air (1 traveler only) to Nigeria and by land (1 traveler) to Senegal. The most severely affected countries were Guinea, Sierra Leone and Liberia due to their poor health systems and infrastructural resources. Zaire species of Filoviridae family was the virus which caused the main outbreak that occurred in West African 2014. Ebola virus disease (EVD), formerly known as Ebola haemorrhagic fever is 
South American Journal of Public Health

Special Edition May 2016

quit severe, very fatal illness in humans. The current outbreak of this virus is the largest, deadliest and most complex since Ebola was discovered in 1976 (WHO, 1978). The disease infects humans through their close contact with infected animals which includes fruit bats, chimpanzees and forest antelope and also spreads between humans by direct contact with infected blood, bodily fluids or organs, or by indirectly through contact with contaminated environments. Attending funerals of Ebola victims is also risky, especially when the mourners have direct contact with that of deceased body. This virus spreads by fusing with cells lining respiratory tract, eyes, body and cavities in which the genetic contents will be released into the cell and take over cells machinery to replicate its self, of which the new copies of the virus are produced and released back to the system.(Dalgard et al., 1992)

The incubation period of the EVD last from two days to three weeks and the diagnosis is quite difficult to obtain. The human disease so far has been limited to Africa, except in Philippines country where one strain cropped up in. (Jehrlug et al., 1990) The EVD average case fatality rate is around $50 \%$ and these case fatality rates have varied from $25 \%$ to $90 \%$ in past outbreaks. (Jehrlug et al., 1990)

EVD diagnosis, EVD diagnosis possesses similar symptoms with that of typhoid fever, malaria and also meningitis. It difficult to distinguish them except with the use of the following investigations: antibody-capture enzyme-linked immunosorbent assay (ELISA);antigen-capture detection tests; serum neutralization test; reverse transcriptase polymerase chain reaction (RT-PCR) assay; electron microscopy and virus isolation by cell culture.(Miranda et al., 1999).

Treatment and vaccines: Healthcare workers are at a very high risk if they treat patients without taking the right precautions to avoid infection. People can also be infectious as long as their blood and secretions contain the virus but in some cases, it will be up to seven weeks after they recover.

Supportive care-rehydration with oral or intravenous fluids can as well be use as the treatment of some specific symptoms, improves survival is the treatment but not yet to be proven treatment available for EVD. However, potential treatments like blood products, immune therapies and drug therapies were currently being evaluated. Experimental vaccines and treatments for Ebola virus disease are still under development, but have not been fully tested for its safety or effectiveness.(Khan et al., 1999)

Prevention and control: Prevention and control measures of Ebola virus disease will depend on applying a good interventions like surveillance, case management, contact tracing, a good laboratory service, having safe burials and social mobilisation, even though community engagement still remain the key to successfully controlling outbreaks.(WHO, 2009)

However, Raising awareness among individuals of the risk factors for Ebola infection and protective measures is an effective way to reduce human transmission.(George et al., 1999)

\section{Significance of the study}

This study is designed with the intent that it will serve as an available reference source and be of good value to researchers in this field; thus updating the existing literature in this subject matter. Moreover, the study will assist government and health administrators of the country in health policy formulation, administration and implementation for better service delivery.

\section{Statement of problem}

WHO (2000), ranked Nigeria's health system as 187th out of 191 World Health Organisation (WHO) member state with an infant mortality rate ranging from 500 per 100,000 in the south West geopolitical zone to 800 per 100,000 infants in the North East Zone. In many developing countries, for instance, Nigeria, they clearly lack universal coverage of health care and little equity. However, EVD is deadly and can kill thousands of people, with no treatment and no vaccine. 


\section{The objectives of this study:}

1. This study is to identify the levels of awareness, attitudes and practices carried out in Enugu State as it concerns the Ebola virus disease.

2. To identify hurdles that needs to be overcome when planning strategies for the control of the spread of the Ebola virus.

3. Use generated evidence to tackle the way forward in Ebola virus disease prevention.

\section{Literature review}

In UNISEF et al., 2014 study, there was a high level of Ebola awareness that was believed to exists in the country (97\% )Sierra Leone and a low level of denial among the respondents.

$74 \%$ of the respondent believes that Bats, monkeys, and wild animals are mostly associated with the cause of the disease. The proportion of people who reject three major misconceptions about Ebola disease and accept three means of preventing the disease is low.

From the study, in the mode of transmission, there is low level of knowledge that EVD could be transmitted through contact with an infected person's blood (32\% ), semen (17\% ), Breast milk (13\% ), and other bodily fluids (43\% )and higher knowledge in shaking hands or other physical contact with an infected person (55\% ), eating or preparing bush meat (52\% ), and eating fruits likely eaten by bats - "bat mot"(33\% ).

However, $80 \%$ majority of the respondents exhibit positive attitudes towards Ebola disease prevention and misconceptions about the prevention and treatment of the disease exist among $20-42 \%$ of the respondents.

The study also revealed that the most preferred means of receiving information about Ebola virus disease was via the radio with $88 \%$ and $60 \%$ of all the respondents viewed health professionals as their most trusted means of obtaining information about the disease. The government as well as the Ministry of health ranked second as a means of acquiring information.

Almost everyone is carrying out at least one positive form of behavioural change. Nevertheless, stigmatisation and discrimination of Ebola patients still exists among the people with a very high level of stigma and discrimination towards Ebola victims such that $76 \%$ of respondents would not be welcome a neighbour who has recovered from Ebola (and provided a Government issued certificate). (UNISEF et al., 2014)

More so, according to (UNISEF et al, 2014), there is $89 \%$ high acceptance of quarantining individuals who have been in direct contact with a person that has been diagnosed with Ebola and over (95\% ) believes that individuals diagnosed with the disease must be admitted in an Ebola Treatment Center. (UNISEF et al., 2014)

\section{Methodology}

\section{Study area}

The descriptive cross sectional study was carried out in Enugu East LGA of Enugu state, Nigeria in 2014. With headquarters as Nkwo Nike, the LGA occupies a land mass of $383 \mathrm{~km} 2$ and has a population of 279,089 (National Population Commission, 2006). The LGA is divided into three communities. The people are mainly farmers, and Igbo speaking. Traditional or Christian religions are predominant. Basic amenities, such as pipe borne water, electricity and good roads, are inadequate or non-existent. There are 37 private clinics and 29 primary health centres in the local government area. There are also several private laboratories and patent medicine dealers.

\section{Study design}

The study employed a cross-sectional design to assess public knowledge, attitudes, and behaviours relating to Ebola Virus Disease (EVD) in Nigeria. In addition, focus group discussions and in-depth interviews were conducted with key informants and various 
South American Journal of Public Health

Special Edition May 2016

Community groups in order to Gain qualitative understanding of Perceived barriers, misconceptions, and bottlenecks In relation to EVD prevention.

The research period spanned between 16th October and December 30th 2014.

\section{Study population}

The study population included local authorities, religious leaders, traditional leaders, health workers, teachers, law enforcement officials, and students, self employed and retired.

\section{Selection criteria}

Selection criteria for the health workers was to be a full time employee in the private and government owned primary health care facilities in the LGA for at least three month, and willingness to give consent for the questionnaire survey. Health workers who were absent on the day of the study were exempted. Graduate and undergraduate who can write, speak and give consent above 15 years.

\section{Sample size}

Sample size for the study was calculated using the formula for descriptive study for populations less than 10,000 (Hayes et al., 1992)with p as $71.0 \%$, being the proportion of health workers with good knowledge of Crimean Congo haemorraghic fever in a study carried out in Turkey (Heymann et al., 1980), z as 1.96 representing a 95\% confidence interval, a desired precision of $10 \%$, and a $10 \%$ nonresponse rate. Sample size is 394 for validity.

\section{Data collection}

Data was collected using structured interviewer administered questionnaire focusing on demographic characteristics, knowledge of Ebola virus disease, and infection control practices. Knowledge of Ebola virus disease was assessed using a set of 29 questions ranging from agent and symptoms of Ebola virus disease to mode of transmission and measures taken in prevention at community and health facility levels. Questions were designed after an intensive literature review.

\section{Data analysis}

Data from the questionnaires were coded and entered into a spread sheet and analysed using SPSS version 15(SPSS, Inc., Chicago, IL, USA). Chi square was used as a tool to analyze the data. All analysis was done at $\mathrm{P}=.05$.

The data collection involved in debt Interview, questionnaire for the client. The questionnaire was $85 \%$ self administered except in about $15 \%$ of the participants in whom it was interviewer-assisted. The questionnaire tool contained information on basic demographic variables such as age, sex and occupation. The dimensions of care evaluated included source of information, concern and fear during the outbreak, if they will want to learn more about EVD, how they can rate their health during the past 2 months, the causes, transmission, precaution measure taken down to prevention

\section{Ethical clearance}

Ethical assent was obtained from the Enugu State Teaching Hospital Ethical committee. Consent was also obtained from Medical directors of the health institutions, and Primary health care Coordinator of the Local Government Area. Informed consent was obtained from all participants. They were told that information given will be treated as confidential and of their right to withdraw from the study any time they wished.

\section{Limitation}

Inability to obtain sufficient sample size among health workers and other government workers due to on-going nationwide strike during the outbreak. Another limitation is that selfreported behaviours may not always be aligned with the individual's actual practices. It is possible that respondents may have provided socially desirable responses; especially due to 
the high awareness of EVD and heavy dose of sensitization and education being undertaken. However, in-depth interviews and focus group discussions probe further and gain a more qualitative understanding of the on the ground realities.

\section{Results}

Table 1: showing sex distribution

\begin{tabular}{|l|l|l|l|l|l|}
\hline \multicolumn{2}{|c|}{} & Frequency & Percent & Valid Percent & Cumulative Percent \\
\hline Valid & male & 186 & 47.2 & 47.2 & 47.2 \\
& female & 208 & 52.8 & 52.8 & 100.0 \\
& Total & 394 & 100.0 & 100.0 & \\
\hline
\end{tabular}

Table 2: showing association between sex and awareness of Ebola

\begin{tabular}{|c|c|c|c|c|c|c|c|c|}
\hline & \multicolumn{5}{|c|}{$\begin{array}{l}\text { How much do you know about Ebola at the time of } \\
\text { outbreak }\end{array}$} & \multirow[t]{2}{*}{ Total } \\
\hline & & & Nothing & little & Some & Much & Very much & \\
\hline \multirow[t]{4}{*}{ Sex } & male & Count & 22 & 98 & 66 & 0 & 0 & 186 \\
\hline & & $\%$ of Total & $5.6 \%$ & $24.9 \%$ & $16.8 \%$ & $.0 \%$ & $.0 \%$ & $47.2 \%$ \\
\hline & female & Count & 0 & 0 & 86 & 68 & 54 & 208 \\
\hline & & \% of Total & $.0 \%$ & $.0 \%$ & $21.8 \%$ & $17.3 \%$ & $13.7 \%$ & $52.8 \%$ \\
\hline \multirow[t]{2}{*}{ Total } & & Count & 22 & 98 & 152 & 68 & 54 & 394 \\
\hline & & \% of Total & $5.6 \%$ & $24.9 \%$ & $38.6 \%$ & $17.3 \%$ & $13.7 \%$ & $100.0 \%$ \\
\hline
\end{tabular}

\section{Chi-Square Test}

\begin{tabular}{|l|l|l|l|}
\hline & Value & df & Asymp. Sig. (2-sided) \\
\hline Pearson Chi-Square & $244.164^{\mathrm{a}}$ & 4 & .000 \\
\hline Likelihood Ratio & 336.893 & 4 & .000 \\
\hline Linear-by-Linear Association & 214.056 & 1 & .000 \\
\hline N of Valid Cases & 394 & & \\
\hline a. 0 cells (.0\%) have expected count less than 5. The minimum expected count is 10.39. \\
\hline
\end{tabular}

\section{Chi-Square test for association between sex and awareness of ebola}

Chi-square result in table above shows that there is a significant association between gender and awareness of Ebola. The result shows that female are more aware of Ebola before the outbreak as $13.7 \%$ of the respondents who were very much aware of Ebola virus were all female while $5.6 \%$ of the respondents who knew nothing about Ebola were all male. Furthermore, our chi-square result shows a p-value less than 0.05 and a Pearson chicalculated value of 244.164 .

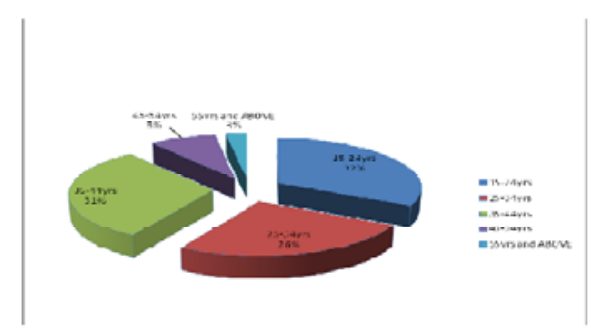

Fig 1: Pie-Chart Showing Age Distribution of Respondents

From the pie chart $89 \%$ of the respondents were between the ages of 15 and 44 years and just $3 \%$ were 55 years 
South American Journal of Public Health

Special Edition May 2016

Table 3: showing chi-square test for association between age and awareness of Ebola

\begin{tabular}{|c|c|c|c|c|c|c|c|c|}
\hline & \multicolumn{5}{|c|}{$\begin{array}{l}\text { How much do you know about Ebola at the time of } \\
\text { outbreak }\end{array}$} & \multirow[b]{2}{*}{ Total } \\
\hline & & & Nothing & little & Some & Much & Very much & \\
\hline \multirow[t]{5}{*}{ Age } & $15-24$ & $\begin{array}{l}\text { Count } \\
\% \text { within } \\
\text { Age } \\
\% \text { of Total }\end{array}$ & $\begin{array}{l}22 \\
17.2 \% \\
5.6 \%\end{array}$ & $\begin{array}{l}30 \\
23.4 \% \\
7.6 \%\end{array}$ & $\begin{array}{l}76 \\
59.4 \% \\
19.3 \%\end{array}$ & $\begin{array}{l}0 \\
.0 \% \\
.0 \%\end{array}$ & $\begin{array}{l}0 \\
.0 \% \\
.0 \%\end{array}$ & $\begin{array}{l}128 \\
100.0 \% \\
32.5\end{array}$ \\
\hline & $25-34$ & $\begin{array}{l}\text { Count } \\
\text { \% within } \\
\text { Age } \\
\% \text { of Total }\end{array}$ & $\begin{array}{l}0 \\
.0 \% \\
.0 \%\end{array}$ & $\begin{array}{l}36 \\
35.3 \% \\
9.1 \%\end{array}$ & $\begin{array}{l}10 \\
9.8 \% \\
2.5 \%\end{array}$ & $\begin{array}{l}56 \\
54.9 \% \\
14.2 \%\end{array}$ & $\begin{array}{l}0 \\
.0 \% \\
.0 \%\end{array}$ & $\begin{array}{l}102 \\
100.0 \% \\
25.9 \%\end{array}$ \\
\hline & $35-44$ & $\begin{array}{l}\text { Count } \\
\text { \% within } \\
\text { Age } \\
\% \text { of Total }\end{array}$ & $\begin{array}{l}0 \\
.0 \% \\
.0 \%\end{array}$ & $\begin{array}{l}32 \\
26.2 \% \\
8.1 \%\end{array}$ & $\begin{array}{l}42 \\
34.4 \% \\
10.7 \%\end{array}$ & $\begin{array}{l}12 \\
9.8 \% \\
3.0 \% \\
\end{array}$ & $\begin{array}{l}36 \\
29.5 \% \\
9.1 \%\end{array}$ & $\begin{array}{l}122 \\
100.0 \% \\
31.0 \% \\
\end{array}$ \\
\hline & $45-54$ & $\begin{array}{l}\text { Count } \\
\text { \% within } \\
\text { Age } \\
\text { \% of Total }\end{array}$ & $\begin{array}{l}0 \\
.0 \% \\
.0 \% \\
\end{array}$ & $\begin{array}{l}0 \\
.0 \% \\
.0 \%\end{array}$ & $\begin{array}{l}18 \\
56.3 \% \\
4.6 \%\end{array}$ & $\begin{array}{l}0 \\
.0 \% \\
.0 \%\end{array}$ & $\begin{array}{l}14 \\
43.8 \% \\
3.6 \%\end{array}$ & $\begin{array}{l}32 \\
100.0 \% \\
8.1 \%\end{array}$ \\
\hline & $\begin{array}{l}55 \text { and } \\
\text { above }\end{array}$ & $\begin{array}{l}\text { Count } \\
\text { \% within } \\
\text { Age } \\
\% \text { of Total }\end{array}$ & $\begin{array}{l}0 \\
.0 \% \\
.0 \%\end{array}$ & $\begin{array}{l}0 \\
.0 \% \\
.0 \%\end{array}$ & $\begin{array}{l}6 \\
60.0 \% \\
1.5 \%\end{array}$ & $\begin{array}{l}0 \\
.0 \% \\
.0 \%\end{array}$ & $\begin{array}{l}4 \\
40.0 \% \\
1.0 \%\end{array}$ & $\begin{array}{l}10 \\
100.0 \% \\
2.5 \%\end{array}$ \\
\hline Total & & $\begin{array}{l}\text { Count } \\
\% \text { within } \\
\text { Age } \\
\% \text { of Total }\end{array}$ & $\begin{array}{l}22 \\
5.6 \% \\
5.6 \%\end{array}$ & $\begin{array}{l}98 \\
24.9 \% \\
24.9 \%\end{array}$ & $\begin{array}{l}152 \\
38.6 \% \\
38.6 \%\end{array}$ & $\begin{array}{l}68 \\
17.3 \% \\
17.3 \%\end{array}$ & $\begin{array}{l}54 \\
13.7 \% \\
13.7 \%\end{array}$ & $\begin{array}{l}394 \\
100.0 \%\end{array}$ \\
\hline
\end{tabular}

Chi-Square Tests

\begin{tabular}{|l|l|l|l|}
\hline & Value & df & Asymp. Sig. (2-sided) \\
\hline Pearson Chi-Square & $298.233 a$ & 16 & .000 \\
Likelihood Ratio & 334.342 & 16 & .000 \\
Linear-by-Linear Association & 73.877 & 1 & .000 \\
N of Valid Cases & 394 & & \\
\hline a. 7 cells (28.0\%) have expected count less than 5. The minimum expected count is .56. \\
\hline
\end{tabular}

\section{Chi-Square Test for Association between Age and Aware of Ebola}

In the above table 3, there is a significant association between age and awareness of Ebola. Result showed that elderly people and those in the middle ages were more aware about Ebola than the younger people between the ages of 15 and 24. A calculated Pearson Chi-Square of 298.2333 and a p value less than 0.05 as contained in table 3 further shows the significant association between age and awareness about Ebola. 


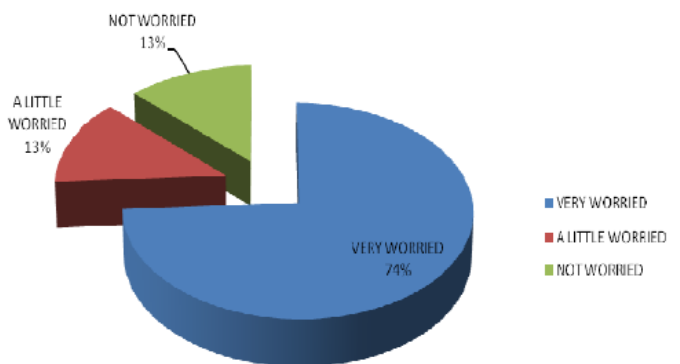

Fig 2: Pie-Chart Showing How Worried Respondent's are about Ebola

Majority (74\%) of the respondents were worried about Ebola Virus Disease

Table 4: Chi-Square Test for Association between Age and Worry about Ebola

\begin{tabular}{|c|c|c|c|c|c|c|}
\hline & & & \multicolumn{3}{|c|}{$\begin{array}{l}\text { How worried are you about } \\
\text { getting Ebola Virus Disease }\end{array}$} & \multirow[b]{2}{*}{ Total } \\
\hline & & & $\begin{array}{l}\text { very } \\
\text { worried }\end{array}$ & $\begin{array}{l}\text { a little } \\
\text { worried }\end{array}$ & $\begin{array}{l}\text { not } \\
\text { worried }\end{array}$ & \\
\hline \multirow[t]{5}{*}{ Age } & $15-24$ & $\begin{array}{l}\text { Count } \\
\% \text { within Age } \\
\% \text { of Total }\end{array}$ & $\begin{array}{l}128 \\
100.0 \% \\
32.5 \%\end{array}$ & $\begin{array}{l}0 \\
.0 \% \\
.0 \%\end{array}$ & $\begin{array}{l}0 \\
.0 \% \\
.0 \%\end{array}$ & $\begin{array}{l}128 \\
100.0 \% \\
32.5 \%\end{array}$ \\
\hline & $25-34$ & $\begin{array}{l}\text { Count } \\
\% \text { within Age } \\
\% \text { of Total }\end{array}$ & $\begin{array}{l}66 \\
64.7 \% \\
16.8 \%\end{array}$ & $\begin{array}{l}36 \\
35.3 \% \\
9.1 \%\end{array}$ & $\begin{array}{l}0 \\
.0 \% \\
.0 \% \\
\end{array}$ & $\begin{array}{l}102 \\
100.0 \% \\
25.9 \%\end{array}$ \\
\hline & $35-44$ & $\begin{array}{l}\text { Count } \\
\% \text { within Age } \\
\% \text { of Total }\end{array}$ & $\begin{array}{l}74 \\
60.7 \% \\
18.8 \%\end{array}$ & $\begin{array}{l}16 \\
13.1 \% \\
4.1 \% \\
\end{array}$ & $\begin{array}{l}32 \\
26.2 \% \\
8.1 \%\end{array}$ & $\begin{array}{l}122 \\
100.0 \% \\
31.0 \%\end{array}$ \\
\hline & $45-54$ & $\begin{array}{l}\text { Count } \\
\% \text { within Age } \\
\% \text { of Total }\end{array}$ & $\begin{array}{l}18 \\
56.3 \% \\
4.6 \%\end{array}$ & $\begin{array}{l}0 \\
.0 \% \\
.0 \% \\
\end{array}$ & $\begin{array}{l}14 \\
43.8 \% \\
3.6 \%\end{array}$ & $\begin{array}{l}32 \\
100.0 \% \\
8.1 \%\end{array}$ \\
\hline & $\begin{array}{l}55 \text { and } \\
\text { above }\end{array}$ & $\begin{array}{l}\text { Count } \\
\text { \% within Age } \\
\% \text { of Total }\end{array}$ & $\begin{array}{l}6 \\
60.0 \% \\
1.5 \%\end{array}$ & $\begin{array}{l}0 \\
.0 \% \\
.0 \%\end{array}$ & $\begin{array}{l}4 \\
40.0 \% \\
1.0 \%\end{array}$ & $\begin{array}{l}10 \\
100.0 \% \\
2.5 \%\end{array}$ \\
\hline \multicolumn{2}{|l|}{ Total } & $\begin{array}{l}\text { Count } \\
\% \text { within Age } \\
\% \text { of Total }\end{array}$ & $\begin{array}{l}292 \\
74.1 \% \\
74.1 \%\end{array}$ & $\begin{array}{l}52 \\
13.2 \% \\
13.2 \%\end{array}$ & $\begin{array}{l}50 \\
12.7 \% \\
12.7 \%\end{array}$ & $\begin{array}{l}394 \\
100.0 \% \\
100.0 \%\end{array}$ \\
\hline
\end{tabular}

Chi-Square Tests

\begin{tabular}{|l|l|l|l|}
\hline & Value & df & Asymp. Sig. (2-sided) \\
\hline Pearson Chi-Square & $154.604 \mathrm{a}$ & 8 & .000 \\
Likelihood Ratio & 177.592 & 8 & .000 \\
Linear-by-Linear Association & 72.028 & 1 & .000 \\
N of Valid Cases & 394 & \multicolumn{3}{|l|}{} \\
\hline a. 4 cells (26.7\%) have expected count less than 5. The minimum expected count is 1.27. \\
\hline
\end{tabular}

\section{Chi-Square Test for Association between Age and Worry about Ebola}

Similarly, in the above table 4, the result confirms relationship between age and level of worry about Ebola. Generally the younger people tend to be more worried about getting Ebola than the older ones.

Table 5: Chi-Square Test for Association between Sex and Worry about Ebola 
South American Journal of Public Health

Special Edition May 2016

\begin{tabular}{|lll|l|l|l|l|}
\hline & & & \multicolumn{3}{|l|}{ getting Ebola Virus Disease } & \\
\hline & & & $\begin{array}{l}\text { very } \\
\text { worried }\end{array}$ & $\begin{array}{l}\text { a little } \\
\text { worried }\end{array}$ & $\begin{array}{l}\text { not } \\
\text { worried }\end{array}$ & Total \\
\hline Age & male & Count & 186 & 0 & 0 & 186 \\
& & \% of Total & $47.2 \%$ & $.0 \%$ & $.0 \%$ & $47.2 \%$ \\
\cline { 2 - 7 } & female & Count & 106 & 52 & 50 & 208 \\
& & \% of Total & $26.9 \%$ & $13.2 \%$ & $12.7 \%$ & $52.8 \%$ \\
\hline \multirow{2}{*}{ Total } & \multirow{2}{*}{$\begin{array}{l}\text { Count } \\
\end{array}$} & \% of Total & 292 & 52 & 50 & 394 \\
& & $74.1 \%$ & $13.2 \%$ & $12.7 \%$ & $100.0 \%$ \\
\hline
\end{tabular}

Chi-Square Tests

\begin{tabular}{|l|l|l|l|}
\hline & Value & df & Asymp. Sig. (2-sided) \\
\hline Pearson Chi-Square & $123.073 a$ & 2 & .000 \\
Likelihood Ratio & 162.374 & 2 & .000 \\
Linear-by-Linear Association & 106.578 & 1 & .000 \\
N of Valid Cases & 394 & & \\
\hline a. 4 cells (26.7\%) have expected count less than 5. The minimum expected count is 1.27. \\
\hline
\end{tabular}

\section{Chi-Square Test for Association between Sex and Worry about Ebola}

Again in table 5 above, the result shows that male were more worried about Ebola than the female. Thus, there is a significant association between gender and awareness of Ebola with a calculated Pearson Chi-Square of 123.073 and a p-value less than 0.05 .

Fig 3: showing Respondent's Knowledge f Ebola before the Outbreak

The level of awareness about EVD is fair with 31\% having quite good knowledge and 38.6 having average knowledge. 5.6\% were completely ignorant f EVD

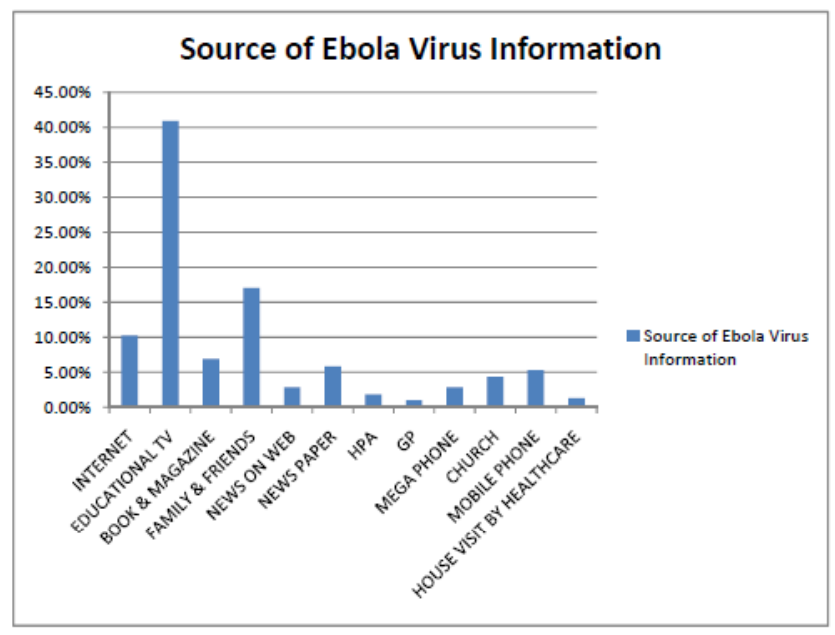

Fig 4: Sources of Ebola information.

It was observed that majority of respondents obtained their information from

Educational TV (42\%), which was followed by family and friends and (18\% )GP General practitioner)was the least of source of information. 


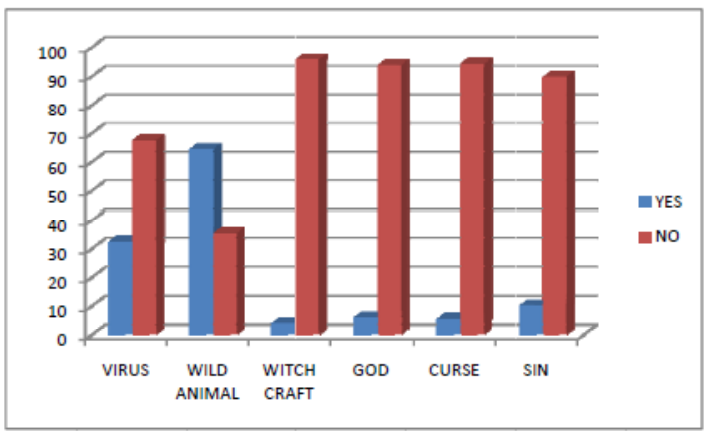

Fig 5: knowledge about causes of Ebola virus

From the above observation in fig 5, the knowledge obtained for the cause of Ebola indicated that EVD is mostly perceived to be caused by wild animal (64.5\%) and followed by virus (32.5\%) with the least being by witch craft (4.1\%)

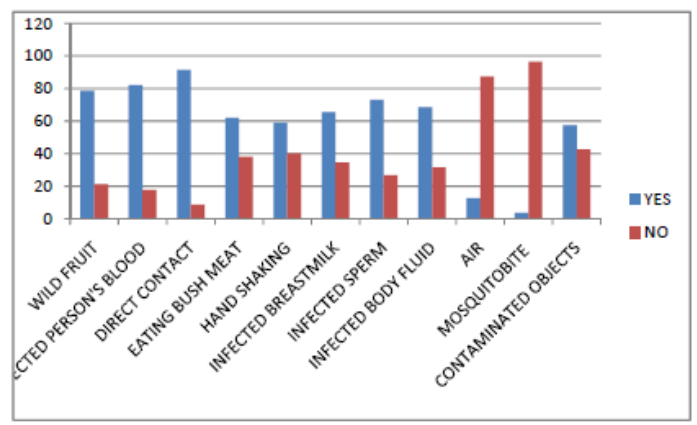

Fig 6: Mode of transmission

In fig 6 above, the respondent's knowledge on transmission mode of Ebola shows (91 $.4 \%$ ) direct contact, (73.1 \% )infected person's sperm, (78.7\% )eating wild animal fruit and the least from mosquito bite(3.6\% ).

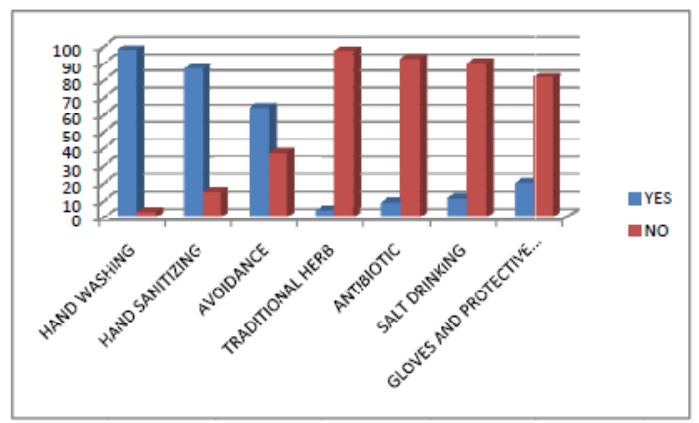

Fig 7: showing measure of precaution taken for EVD.

In fig 7 , there were three precautionary measures mostly observed during the outbreak which involve (97\%) hand washing, followed by (85.8\%) hand sanitizing and (63.5\%) avoidance. The least measure being drinking of traditional herbs(3.6\%) 


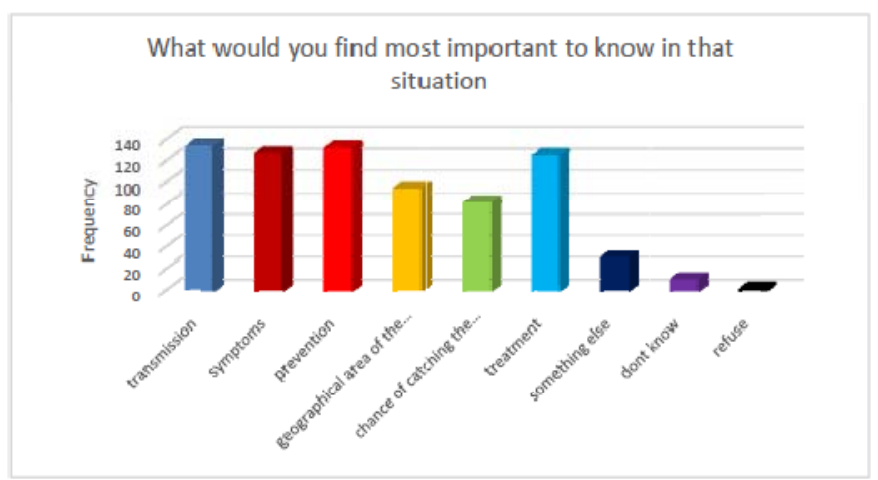

Fig 8: Mostly important information respondents want to know.

In Fig 8, it was observed that the priority areas of interest were transmission prevention, and treatment.

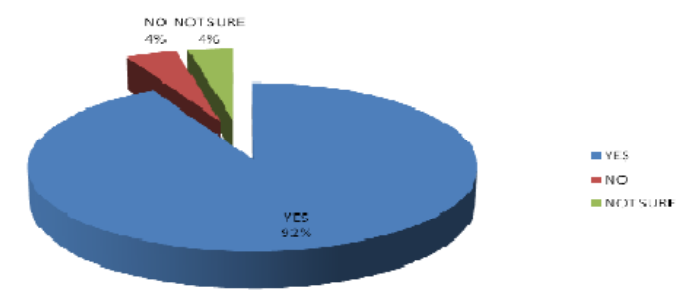

Fig 9: Pie-Chart Showing Whether Respondents Want to Learn More about EVD.

In the above chart (fig 9), greater majority (92\%) want to learn more about EVD. Also in knowledge of prevention of EVD: Comprehensive knowledge on EVD prevention is generally low. Only $35 \%$ of respondents were able to identify three means of prevention and rejected three misconceptions.

\section{Discussion}

The subject of EVD is quite rare in literature partly due to the rarity of the disease. Secondly, there is less research consciousness in Africa where Ebola virus is prevalent. These factors may explain where there is virtually one prominent research done (Sierra Leone) on which this study can be compared with.

There was more information about EVD by female when compared to males. An important contributory factor may be because women visit the hospitals more than men.

There high level of worry (74\% )about EVD especially amongst youths. The explanation for this may be due to the fatality of the disease which can be used to an advantage to increase the level of awareness of the disease.

It was observed that majority of respondents obtained their information from Educational TV (42\% ).This corroborates with the study done in Sierra Leone by UNICEF in which radio was the preferred means of receiving information though at a higher percentage of $88 \%$.

Figure 5 showed that majority of the respondents identified wild animals and virus as the cause of EVD. This agrees with the UNICEF study which was specific that bats were the main culprits perceived by respondents as the cause of the disease.

From this study, on the mode of transmission, there is fairly high knowledge in which respondents felt the direct contact with infected persons (91.4\% )were the major mode of transmission. This is different from the low level of knowledge by respondent in Sierra Leone that EVD could be transmitted through contact with an infected person's blood (32\% ), semen (17\% ), Breast milk (13\% ), and other bodily fluids (43\% ). 


\section{Conclusion}

The level of knowledge about EVD is fairly reasonable amongst resident of Enugu metropolis in south east Nigeria. There are fewer misconceptions about EVD when compared to Sierra Leone coupled with the willingness of the people to acquire more information through the mass media. This must have contributed to the timely containment of Ebola virus Disease in Nigeria. Also the health policy on ground in Nigeria borrowed heavily from the good practices implemented in the polio programme by establishing an Emergency Operation Centre (EOC), led by the Incident Manager, using an Incident Management System (IMS)to coordinate the response and consolidate decision making.

\section{Recommendation}

- An aggressive government response and effective contact tracing would help keep the virus in check.

- Strong public awareness campaigns, teamed with early engagement of traditional, religious and community leaders, will also play a major role in successful containment of this outbreak.

- Risk reduction messaging should focus on several factors: reducing the risk of wildlife-tohuman transmission; reducing the risk of human-to-human transmission; outbreak containment measures.

- The use of the local language of the people as an effective means of spreading messages about the virus should be encouraged.

- Clarifying misconceptions surrounding the knowledge, attitudes and practices of the people is advised.

- Focus should be drawn to addressing community acceptance of Ebola disease affected people.

- Maximise the use of the mass media to pass across messages to the people, especially the radio and television to pass messages across as well as the use of the television to enable survivors tell their stories.

- Community ownership and participation should be encouraged especially at the grassroots level.

- The health professionals and the Ministry of health are key to providing information to the general public.

\section{References}

[1.] Centers for Disease Control. (2014)Update: Filovirus infection in animal handlers. Morbidity Mortality Weekly Report. 2014; 39(13):221.

[2.] Dalgard D. W (1992). Combined Simian Hemorrhagic Fever and Ebola Virus Infection in Cynomolgus Monkeys. Laboratory Animal Science 1992; 42(2): 152-5

[3.] Georges A. J, Leroy E. M and Renaud A. A, (1999). Ebola hemorrhagic fever outbreaks in Gabon, 1994-1997: epidemiologic and health control issues. Journal of Infectious Diseases. 1999; 179: S65-75. [4.] Hayes C. G, Burans J. P and Ksiazek T. G (1992). Outbreak of fatal illness among captive macaques in the Philippines caused by an Ebola-related filovirus. American Journal of Tropical Medicine and Hygiene. 1992;46(6):664-671.

[5.] Heymann D. L, Weisfeld J. S and Webb P. A (1980). Ebola hemorrhagic fever: Tandala, Zaire, 1977-1978. Journal of Infectious Diseases. 1980;142(3):372-376.

[6.] Jahrling P. B, Geisbert T. W and Dalgard D. W (1990). Preliminary report: isolation of Ebola virus from monkeys imported to USA. Lancet. 1990;335(8688):502-505.

[7.] Khan A. S, Tshioko F. K and Heymann D. L, (1999). The Reemergence of Ebola Hemorrhagic Fever, Democratic Republic of the Congo, 1995. Journal of Infectious Diseases. 1999; 179: S76-S86.

[8.] Ministry of Health Nigeria - Ebola report, 24th July 2014, Lagos[469 KB, 5 pages]

[9.] Miranda M. E, Ksiazek T. G and Retuya T. J (1999). Epidemiology of Ebola (subtype Reston) virus in the Philippines, 1996. Journal of Infectious Diseases. 1999; 179 (suppl 1 ):S115-S119. 
South American Journal of Public Health

Special Edition May 2016

[10.] UNICEF, FOCUS 1000, \& Catholic Relief Services. (2014). Study on Public Knowledge, Attitudes, and Practices Related to EVD Prevention and Medical Care in Sierra Leone. Sierra Leone: UNICEF, FOCUS 1000 \& Catholic Relief Services.

[11.] World Health Organization. Ebola haemorrhagic fever in Sudan, 1976. Report of a WHO/International Study Team [1 .4 MB, 24 pages]. Bulletin of the World Health Organization. 1978;56(2):247-270. 25

[12.] World Health Organization. Ebola haemorrhagic fever in Zaire, 2000[958 KB, 24 pages]. Report of an International Convention. Bulletin of the World Health Organization. 1978; 56(2):271 -293.

[13.] World Health Organization. End of the Ebola Outbreak in the Democratic Republic of the Congo. Global Alert and Response. 17 Febuary 2009

[14.] World Health Organization. Viral haemorrhagic fever in imported monkeys [1 .2 MB, 8 pages]. Weekly Epidemiological Record. 2014;67(24):183. 26 